Jpn. J. Med. Sci. Biol., 49, 209-218, 1996.

\title{
CARCINOGEN-INDUCED DE NOVO METHYLATION IN $c$-myc EXON I
}

\author{
Gensaku OKADA, Kazuo RYOYAMA1, Takahiro NOMURA2, \\ Takashi MOMOI3, Hiroyuki TSUCHIYA4, Tadanori KAMEYAMA2 \\ and Kazuo YAMAGUCHI5
}

Department of Immunobiology, 1 Experimental Therapeutics, and 2Molecular Biology, Cancer Research Institute and 5 Institute for Gene Research, and 4Department of Orthopaedic Surgery, School of Medicine, Kanazawa University, 13-1 Takaramachi, Kanazawa 920, 3Division of Development and Differentiation, National Institute of Neuroscience, NCNP, Ogawahigashi-machi, 4-1-1, Kodaira-shi, Tokyo 187

(Received August 26, 1996. Accepted November 14, 1996)

SUMMARY: During the response of $N$-methyl- $N$-nitro- $N$-nitrosoguanidine (MNNG), methylation occurred at the Hpa II site of c-myc exon I, which is located downstream of the P1 initiation site, as evidenced by the assays of Hpa II-PCR. The Hpa II spite of the 5' flanking region did not undergo methylation. UVirradiation also led to methylation in exon I. The extent of methylation increased depending on the dose of MNNG and UV. The results suggested that methylation takes place in transcriptionally active c-myc responsible for carcinogens and is caused by mechanisms different from that of alkylation in a specific $\mathrm{CpG}$ site. Possible contribution of methylation to less repair found in c-myc is discussed.

岡田源作(金沢大学がん研究所免疫生物部 猟山一雄(金沢大学がん研究所化学療法部 金沢市宝町13-1) 野村孝弘(金沢大学がん研究所分子生物部 金沢市宝町13-1) 桃井＼cjkstart隆(国立精神·神経センター神経研究所 小平市小川東町4-1-1)

土屋弘行(金沢大学医学部整形外科 金沢市宝町 13-1)

亀山忠典(金沢大学がん研究所分子生物部 金沢市宝町13-1)

山口和男(金沢大学遺伝子実験施設 金沢市宝町13-1)) 


\section{INTRODUCTION}

A cluster of mutations is often found in the first exon of c-myc (1) and the possible involvement of mutated c-myc in human carcinogenesis (2) has been suggested. Recent studies (2-4) have suggested not only less repair in c-myc after DNA damage by MNNG or UV but also a causal relationship between less repair and mutation of $\mathrm{c}-\mathrm{myc}$, although the cause of inefficient repair is uncertain.

Accumulated evidence $(3,5)$ has suggested that transcriptionally active DNA is easily damaged or susceptible to the adduct formation by DNA-alkylating agents. The adduct formation in active genes causes de novo methylation in their GC-rich sequences $(6,7)$, since guanine residues are major sites for alkylation in DNA. These previous studies suggest that methylation can occur in the transcribed GC-rich sequences during the response of chemical carcinogens. We have shown that MNNG causes the induction of c-myc in HeLa S3 cells (8). We have been interested in examining de novo methylation in c-myc that is actively transcribed or preferentially damaged (3) during the MNNG response. It is known that exposure to UV has also led to the accumulation of the oncoprotein in human tumor cells (9). We further investigated to find whether or not specific DNA damages are involved in methylation. DNA modification was tested by analyzing the level of methylation following exposure to UV, which induces cyclobutane pyrimidine dimers in DNA.

\section{MATERIALS AND METHODS}

Cell culture: HeLa S3 cells were routinely cultured at $37 \mathrm{C}$ in $5 \% \mathrm{CO}_{2} / 95 \%$ air in Dulbecco's Modified Eagle Medium supplemented with $4 \mathrm{mM}$ L-glutamine, $100 \mathrm{U} / \mathrm{ml}$ penicillin, $100 \mu \mathrm{g} / \mathrm{ml}$ streptomycin, and 10\% fetal calf serum (GIBCOBethesda Research Laboratories, Gaithersburg, MD) (growth medium).

Exposure to MNNG or UV lights: Before MNNG exposure, exponentially growing HeLa cells $(3 \times 106$ per $100-\mathrm{mm}$ plate) were washed once with phosphatebuffered saline (PBS) and immersed in fresh prewarmed, serum-free growth medium. Since MNNG is a labile carcinogen, it was prepared in PBS just before use. Prior to irradiation, the growth medium was removed and stored at $37 \mathrm{C}$. After rinsing with PBS, the cells were irradiated with a germicidal UV lamp (Toshiba, Tokyo, $254 \mathrm{~nm}$ ) at a dose rate of $0.4 \mathrm{~J} / \mathrm{m}^{2}$ and further incubated in the original medium. 
After $12 \mathrm{hr}$ of incubation, the cells were washed once with PBS prior to preparing genomic DNA.

Preparation of genomic DNA: DNA for PCR was prepared by the method using guanidine $\mathrm{HCl}(10)$.

Hpa II digestion and control for digestion by Southern blot hybridization: DNA aliquots of $5 \mu \mathrm{g}$ were digested with Hpa II (20-25 units) for $12 \mathrm{hr}$ at $37 \mathrm{C}$ as recommended by the supplier (Takara, Shiga). Following digestion, DNA was extracted with phenol-chloroform and precipitated with ethanol. To assess the Hpa II digestion, $0.05 \mu \mathrm{g}$ of $\phi \mathrm{X} 174 \mathrm{RF}$ I DNA was co-digested with parallel aliquots of genomic DNA, electrophoresed, and transferred to a nylon membrane (Hybond $\mathrm{N}$, Amersham International plc., Buckinghamshire, UK). The membrane was hybridized with 32P-labeled phage DNA and autoradiographed to confirm the complete loss of undigested phage DNA.

DNA for the probe was labeled with [ $\alpha-32 \mathrm{P}] \mathrm{dCTP}$ (Amersham) and a random priming labeling kit (Takara) according to the manufacturer's instructions.

Analysis by Hpa II-PCR: Singer-Sam et al. (11) have used their Hpa II-PCR method to assay the methylation status of the Hpa II site in the mouse 3phosphoglycerate kinase 1 (Pgk-1) gene. We designed here two sets of three primers and PCR conditions to use for the oncogene analysis, based upon the study of the Pgk-1 gene. A primer set analyzed on Hpa II site 1 (nucleotides - 103 with respect to the P1 promoter, Fig. 1A) was:

5'primer 1;5'-ACCCTCCCCACCCTCCCCATAAG-3',

3'primer; 5'-TTATACTCAGCGCGATCCCTCCC-3', and 5' primer 2;5'CCCCACCCTCCCCATAAGAAAAAAGATCCTCTCTCGC-3'.

Another primer set for the Hpa II site 2 (nucleotides +272) was:

5'primer 1;5'-TGCGCTGCGGGCGTCCTGGGAA-3', 3' primer; 5'-GCAAGGAGAGCCTTTCAGAGAAG-3', and 5' primer 2;5'GCTGCGGGCGTCCTGGGAAGCCCTCCCGCTGATCCCCCA-3'.

Reaction mixtures $(20 \mu \mathrm{l})$ containing 250 nmoles of Tris- $\mathrm{HCl}, \mathrm{pH} 8.8,1.25$ $\mu$ moles of $\mathrm{KCl}, 37.5$ nmoles of $\mathrm{MgCl}_{2}, 25 \mu \mathrm{g}$ of Triton X100, 15.3 pmoles of $5^{\prime}$ primer 1, 72 fmoles of $5^{\prime}$ primer 2, 16 pmoles of $3^{\prime}$ primer and $1 \mu \mathrm{g}$ of genomic DNA were overlaid with $20 \mu$ l of mineral oil, denatured at $95 \mathrm{C}$ for $5 \mathrm{~min}$, and then cooled to $66 \mathrm{C}$ by using a Perkin-Elmer/Cetus (Norwalk, CA) DNA Thermal Cycler. A JumpStart kit (BioVentures Inc., Memphis, TN, $5 \mu$ l, a kit contains 5 nmoles of four dNTPs) and Taq polymerase (Wako, Osaka, 1.25 units) were added to the reaction mixtures. Routine amplifications were performed with 30 cycles of denaturation for $1.0 \mathrm{~min}$ at $95 \mathrm{C}$, annealing for $1.5 \mathrm{~min}$ at $66 \mathrm{C}$, and extension at $73 \mathrm{C}$ for $1.0 \mathrm{~min}$. PCR products $(5 \mu \mathrm{l})$ were electrophoresed on $4 \%$ NuSieve GTG agarose (FMC BioProducts, Rockland, ME) gels in a 1 x TBE buffer (89 mM Tris and $89 \mathrm{mM}$ borate, $\mathrm{pH} 8.2$ and $2 \mathrm{mM}$ EDTA) and visualized by staining with 
ethidium bromide. The amount of DNA was estimated by using 4', 6-diamidino2-phenylindole dihydrochloride (Nippon Gene, Tokyo).

Quantitation of the level of methylation: The extent of methylation was determined by parallel PCR assays in which 5' primer 2 was omitted. After electrophoresis, the DNA was transferred to a nylon membrane and hybridized with a 32P-labeled Pvu II fragment (nucleotides -352 to +511 , Fig. 1A) prepared from $p M y c 6514$ prior to autoradiography. The autoradiographs were analyzed with a Bio-Image Analyzer (Fujix BA100, Tokyo).

The level of methylation (\%) was determined by dividing the signal from the PCR products after Hpa II digestion by that of the PCR products not digested with Hpa II and multiplying by 100 .

\section{RESULTS}

\section{Methylation at the Hpa II Site 2 of c-myc Exon I}

The Hpa II site 2 is an unmethylated $\mathrm{CpG}$ site located downstream of the P1 initiation site (Fig. 1A) and is an amenable CCGG site for restriction enzyme analysis (12). As shown in Fig. 1B, methylation at this site can be detected by a 269 bp PCR product in proportion to the amounts of amplifiable, methylated DNA remaining after Hpa II digestion. Since the Hpa II-PCR assay was devised originally for quantitating the levels of methylation (11), we investigated to find how the level of methylation is changed by doses of MNNG (Fig. 1C). Enhancement of methylation, represented by elevated levels of $269 \mathrm{bp}$ product, was evident, exhibiting a dose-dependent induction by MNNG of up to $1.2 \mu \mathrm{g} / \mathrm{ml}$. The variable detection of methylation was not due to incomplete $H p a$ II digestion, since it was controlled by observing the complete digestion of $\phi \mathrm{X} 174$ DNA added to the parallel reactions (data not shown). Furthermore, an almost constant level of a 226 bp product was observed, indicating the same amounts of DNA among the DNA samples in the PCR assays. The methylation levels at $1.2 \mu \mathrm{g} / \mathrm{ml}$ of MNNG reached nearly $99 \%$ (Table I) when the levels obtained as a template with the undigested DNA (data not shown) were indicated as $100 \%$.

\section{The Methylation State of Hpa II Site 1}

We investigated to find whether or not methylation occurs at an $\mathrm{Hpa}$ II site located upstream of the P1 initiation site (Fig. 2). The background level of the $271 \mathrm{bp}$ PCR product was detected when hypomethylated DNA obtained from the 
Fig. 1A
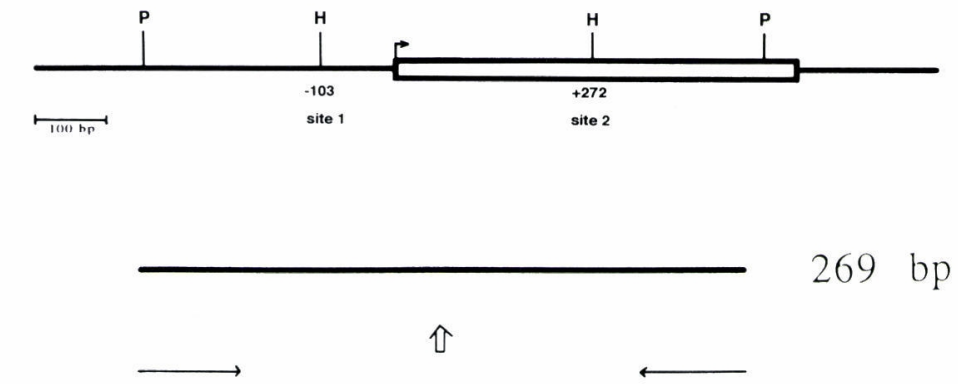

Fig. 1B

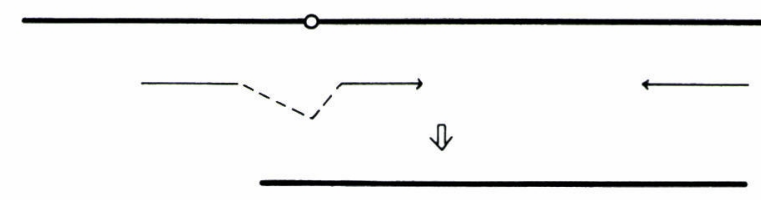

Fig. 1C

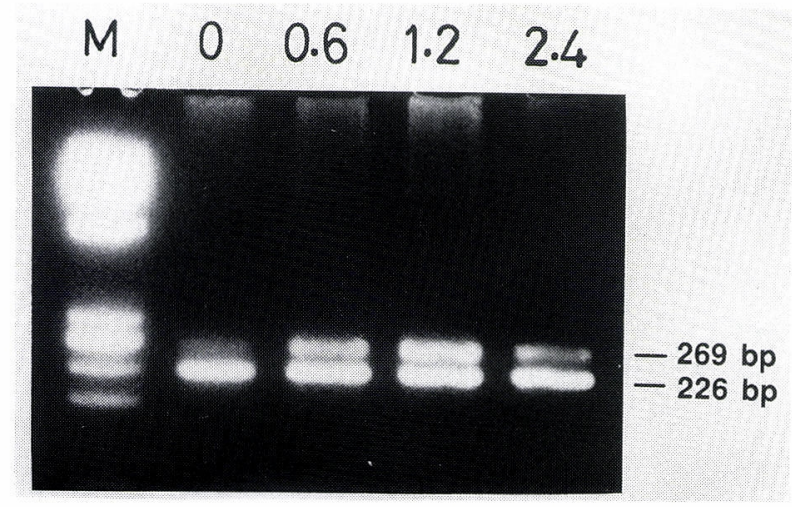

Fig. 1. Hpa II-PCR assay of methylation at Hpa II site 2. (A) is the location of the analyzed Hpa II sites surrounding c-myc exon I, which is represented by a box. The base numbers indicate the $\mathrm{P} 1$ initiation site (the arrow) as +1. P, Pvu II. H, Hpa II. (B) shows primer design and relevant products for the PCR-aided assays of Hpa II-digested DNA in the diagram. Hpa II site 2 is marked as an open circle on a centered thick line. The thin arrows represent two pairs of primers (5' primer 1 and $3^{\prime}$ primer) designed as described in Materials and Methods. The dotted line indicates a deleted portion of genomic DNA in the primer (5' primer 2). Two thick lines are PCR products derived from the respective primers. (C) shows ethidium bromide staining of the PCR products on agarose gel. Genomic DNA was prepared from the cells treated with the indicated doses $(\mu \mathrm{g} / \mathrm{ml})$ of MNNG. Markers $(\mathrm{M})$ are an Hae IIIdigest of $\phi \mathrm{X} 174$. 


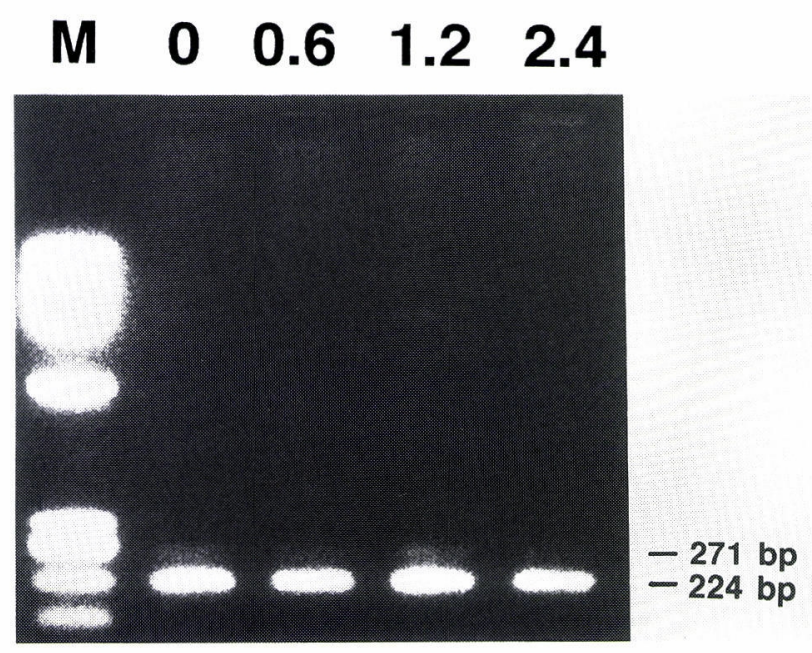

Fig. 2. Hpa II-PCR assay on Hpa II site 1 . The assay was carried out by using genomic DNA prepared from the MNNG-exposed cells at the indicated doses $(\mu \mathrm{g} / \mathrm{ml})$. Markers are shown as in Fig. $1 \mathrm{C}$.

mock-treated cells was used as a template. The PCR products of DNA obtained from MNNG-exposed cells were not greater in concentration than the background level for this site, although the assays were carried out under conditions in which the reference PCR products (224 bp) were efficiently synthesized by each DNA sample. The findings suggested that site 1 appears to be scarcely methylated and remains unmodified after post-treatment with MNNG.

The Effect of UV-irradiation on Site-specific Methylation

The results in Table I indicate that the Hpa II site 2 also undergoes methylation following exposure to UV. UV-irradiation, at doses reducing the cell survival to $80-37 \%$ (8), increased dose-dependently the level of methylation. 
Table I. Carcinogen-induced methylation by Hpa II-PCR assay

\begin{tabular}{llc}
\hline & Dose & $\begin{array}{c}\text { Levels of methylation } \\
(\%)^{*}\end{array}$ \\
\hline MMNG $(\mu \mathrm{g} / \mathrm{ml})$ & 0 & 20 \\
& 0.6 & 65 \\
& 1.2 & 99 \\
& 2.4 & 60 \\
\hline & 0 & 19 \\
$\mathrm{UV}\left(\mathrm{J} / \mathrm{m}^{2}\right)$ & 3.0 & 60 \\
& 7.0 & 99 \\
\hline
\end{tabular}

*The relative levels of methylation as compared with those (100\%) given by Hpa II-PCR assay using genomic DNA without Hpa II digestion.

\section{DISCUSSION}

This is the first report showing that MNNG and UV cause de novo methylation in c-myc. Methylation during the cellular response to carcinogens is thought to be associated with maintenance methylation reaction which occurs in the repair patches (13). There is, however, substantial evidence (6,7) suggesting that some types of DNA alkylation cause apparent de novo methylation in the GC-rich sequences. It has been suggested that the steric fluctuation in DNA caused by alkylation adducts enhances the maintenance methylation in the opposite strand and the subsequent methylation at the side of the alkylated strand accomplishes de novo methylation (14). Although DNA adducts could mediate the signal for methylation, methylation in c-myc appears to be unrelated to DNA adduct formation in the GC-rich sequences of exon I. We observed the decrease in the level of methylation at a higher dose of MNNG than $1.2 \mu \mathrm{g} / \mathrm{ml}$ (Fig. 1C), although the question of why methylation did not increase at a high cytotoxic dose of MNNG is unanswered. The observation may support our assumption, since further increase in the methylation level might be expected if the occurrence of 
methylation is simply attributed to DNA adducts. Furthermore, the adductdependent methylation was not induced by UV-irradiation (6), whereare UVirradiation can cause methylation in c-myc (Table I). The mechanism causing methylation in c-myc should await future studies.

Singer-Sam et al. (11) have assayed a specific Hpa II site of the Pgk-1 gene whose modification had a profound influence on its expression. Our results indicated the occurrence of methylation in exon I, which is involved in the regulation of transcriptional elongation. We have not, however, addressed the question of the mechanism by which methylation has an influence on the carcinogenregulated expression of c-myc. Our results suggested that both methylation (data not shown) and transcript accumulation (8) reached peak levels at 12-13 hr after stimulation and that both events increased with dependence on the dose of MNNG. Carcinogen-induced methylation thus appears to occur in actively expressed c-myc. Although methylation on active genes is rare in adult cells and exon I is usually an unmethylated portion of the CpG island (12), it has been reported that methylation in active c-myc can be observed in humans even under normal physiological conditions (15). Tissue-specific methylation appears to occur irrespective of the promoter function, although its physiological significance is uncertain. This finding raises the possibility that carcinogen-induced methylation might also be a DNA modification regardless of oncogene expression.

Methylation within the $\mathrm{CpG}$ islands can contribute to alteration of the chromatin structure (16). As has been suggested by DNase I-digestion analysis (7), carcinogen-induced methylation could also lead to change in the chromosomal assembly of the CpG island in the Thy- 1 gene, whose expression is not always regulated by methylation. We propose the notion that methylation and the subsequent change in chromatin structure may be a cause of poor repair found in c-myc after DNA damage, since these epigenetic changes have been shown capable of interfering with the accessibility of DNA alkylation adducts (17) or pyrimidine dimers (18) to repair enzymes. This notion is underscored by the fact that some tumor cells have mutations around the CpG site in exon I (19), at which we have observed methylation. Since it is likely that multiple sites of methylation favor alteration of the chromatin structure, study of methylation at the other $\mathrm{CpG}$ sites should shed light on the inefficient execution of repair in c-myc. 


\section{ACKNOWLEDGMENTS}

The authors thank Dr. Osamu Nikaido, Faculty of Pharmaceutical Sciences, for his advice, Dr. Morinobu Takahashi, Cancer Research Institute, for his critical comments, and Japanese Cancer Research Resources Bank for providing pMyc 6514.

\section{REFERENCES}

1. Szajnert, M.-F., Saule, S., Bornkamm, G. W., Wajcman, H., Lenoir, G. M. and Kaplan, J.-C. (1987): Clustered somatic mutations in and around first exon of non-rearranged c-myc in Burkitt lymphoma with $t(8 ; 22)$ translocation. Nucleic Acids Res., 15, 4553-4565.

2. Bianchi, N. O., Bianchi, M. S., Alitalo, K. and De la Chapelle, A. (1991): UV damage and repair in the domain of the human c-myc oncogene. DNA Cell Biol., 10, 125-132.

3. Chary, P., Mitchell, C. E. and Kelly, G. (1991): Chemical carcinogeninduced damage to the c-neu and c-myc protooncogenes in rat lung epithelial cells: possible mechanisms for differential repair in transcriptionally active genes. Cancer Lett., 58, 57-63.

4. Beecham, E. J., Mushinski, J. F., Shacter, E., Potter, M. and Bohr, V. A. (1991): DNA repair in the c-myc proto-oncogene locus: possible involvement in susceptibility or resistance to plasmacytoma induction in BALB/c mice. Mol. Cell. Biol., 11, 3095-3104.

5. Lu, S.-J., Milligan, J. R. and Archer, M. C. (1991): Preferential methylation of the Ha-ras proto-oncogene by methylnitrosourea in rat mammary glands. Mol. Carcinog., 4, 261-264.

6. Ivarie, R. D. and Morris, J. A. (1982): Induction of prolactin-deficient variants of $\mathrm{GH}_{3}$ rat pituitary tumor cells by ethyl methanesulfonate: reversion by 5 -azacytidine, a DNA methylation inhibitor. Proc. Natl. Acad. Sci. USA, 79, 2967-2970.

7. Sneller, M. C. and Gunter, K. C. (1987): DNA methylation alters chromatin structure and regulates Thy-1 expression in EL-4 T cells. J. Immunol., 138, 3505-3512.

8. Okada, G., Reungmaneepaitoon, S., Nakano, K., Nomura, T., Tokuyama, H., Ryoyama, K., Yamaguchi, K. and Kameyama, T. (1995): A Mer ${ }^{-}$phenotype of ethionine-resistant HeLa S3 variants. In Vitro Cell. Dev. Biol. Anim., 31, 168-170.

9. Sullivan, N. F. and Willis, A. E. (1989): Elevation of c-myc protein by DNA strand breakage. Oncogene, 4, 1497-1502. 
10. Bowtell, D. D. L. (1987): Rapid isolation of eukaryotic DNA. Anal. Biochem., 162, 463-465.

11. Singer-Sam, J., LeBon, J. M., Tanguay, R. L. and Riggs, A. D. (1990): A quantitative HpaII-PCR assay to measure methylation of DNA from a small number of cells. Nucleic Acids Res., 18, 687.

12. Cheah, M. S. C., Wallace, C. D. and Hoffman, R. M. (1984): Hypomethylation of DNA in human cancer cells: a site-specific change in the cmyc oncogene. JNCI, 73, 1057-1065.

13. Kastan, M. B., Gowans, B. J. and Lieberman, M. W. (1982): Methylation of deoxycytidine incorporated by excision-repair synthesis of DNA. Cell, 30, 509-516.

14. Farrance, I. K. and Ivarie, R. (1985): Ethylation of poly(dC-dG)·poly(dC-dG) by ethyl methanesulfonate stimulates the activity of mammalian DNA methyltransferase in vitro. Proc. Natl. Acad. Sci. USA, 82, 1045-1049.

15. Bianchi, N. O., Bianchi, M. S., Alitalo, K. and De la Chapelle, A. (1989): The methylation pattern of normal and truncated amplified human c-myc oncogenes. Biochim. Biophys. Acta, 1007, 350-355.

16. Lewis, J. and Bird, A. (1991): DNA methylation and chromatin structure. FEBS Lett., 285, 155-159.

17. Bentivegna, S. S. and Bresnick, E. (1994): Inhibition of human O6methylguanine-DNA methyltransferase by 5-methylcytosine. Cancer Res., 54, 327-329.

18. Ishiwata, K. and Oikawa, A. (1982): Chromatin structure interferes with excision of abnormal bases from DNA. Biochim. Biophys. Acta, 698, 15-21.

19. Pelicci, P.-G., Knowles II, D.M., Magrath, I. and Dalla-Favera, R. (1986): Chromosomal breakpoints and structural alterations of the c-myc locus differ in endemic and sporadic forms of Burkitt lymphoma. Proc. Natl. Acad. Sci. USA, 83, 2984-2988. 